\title{
Analisis Tingkat Kematangan Proses Bisnis dan Kesiapan Teknologi Informasi Studi Perusahaan Garmen Mikro, Kecil, dan Menengah di Jawa Timur
}

\author{
Nadya Chandra Rosianti, Mahendrawathi ER., dan Amna Shifia Nisafani \\ Departemen Sistem Informasi, Fakultas Teknologi Informasi, Institut Teknologi Sepuluh Nopember \\ (ITS) \\ e-mail: mahendrawathi.er@gmail.com
}

\begin{abstract}
Abstrak-UMKM merupakan salah satu pilar utama Indonesia dalam menggerakkan ekonomi negara. Seiring berkembangnya teknologi informasi saat ini, UMKM harus meningkatkan inovasi karena ketatnya persaingan bisnis, baik di pasar domestik maupun internasional. Salah satu strategi peningkatan daya saing UMKM adalah pendampingan serta peningkatan kapasitas teknologi informasi. Dilihat dari kondisi UMKM saat ini, mayoritas UMKM gagal mengimplementasikan TI karena adanya ketidaksesuaian antara tingkat kesiapan TI dengan infrastruktur TI yang diimplementasikan. Sebagai penentu keputusan, pemilik UMKM perlu memahami pentingnya mengetahui tingkat kematangan proses bisnis yang dimiliki usahanya jika dilihat dari aspek kesiapan TI. Penelitian ini mengukur tingkat kematangan proses bisnis dan kesiapan penerapan TI pada perusahaan garmen berskala kecil

$B$
\end{abstract} berdasarkan metode Business Process Orientation Maturity Model dari McCormack dan Johnson. Penelitian ini akan dilakukan secara kualitatif dengan melakukan observasi dan wawancara pada sepuluh perusahaan garmen berskala kecil di Jawa Timur. Penelitian ini berbasis studi kasus karena penelitian ini membutuhkan jawaban yang lebih mendalam dan bersifat lebih jelas yang dapat diperoleh dengan kategori "bagaimana" dan "mengapa". Untuk aspek Dukungan Sistem Informasi pada BPMM, penelitian ini menjabarkan dukungan TI untuk bisnis dengan kesiapan penerapan TI. Hal ini dilakukan karena aspek Dukungan Sistem Informasi pada metode BPOMM McCormack dan Johnson lebih berfokus pada perusahaan yang telah mengimplementasikan TI, sedangkan mayoritas UMKM di Indonesia belum mengimplementasikan TI. Aspek penilaian kesiapan penerapan TI yang digunakan adalah infrastruktur TI, aplikasi TI, dan sumber daya manusia TI. Dari sampel perusahaan garmen tersebut, maka dapat dipetakan karakteristik dan kecenderungan kesiapan TI yang dimiliki. Pada penelitian ini diperoleh nilai kematangan proses bisnis dan kesiapan penerapan teknologi informasi dari sepuluh UMKM garmen yang diteliti. Untuk nilai kematangan proses bisnis, 9 UMKM berada pada Tingkat 1 yaitu Ad hoc dan 1 UMKM berada pada Tingkat 2 yaitu Defined. Sedangkan nilai kesiapan penerapan teknologi informasi terbagi menjadi 3 kategori, yaitu 3 UMKM berada di tingkat rendah, 3 UMKM berada di tingkat sedang, 2 UMKM berada di tingkat tinggi, dan 2 UMKM saling bertolak belakang. Hasil akhir dari penilaian dua elemen tersebut dikaitkan dan diprofilkan menjadi empat, yaitu sama-sama tinggi, sedang, rendah, dan bertolak belakang.

Kata Kunci-Proses bisnis, usaha kecil, garmen, Business Process Management, Business Process Maturity Model, IT Readiness

\section{PENDAHULUAN} ELUM kokohnya perekonomian Indonesia saat ini mendorong pemerintah untuk terus memberdayakan UMKM yang menyerap tenaga kerja cukup besar dan memberi peluang untuk berkembang dan bersaing dengan perusahaan yang menggunakan modal besar (capital intensive). Eksistensi UMKM tidak dapat diragukan lagi karena terbukti bertahan dan menjadi roda penggerak ekonomi, terutama pasca krisis ekonomi [1].

Di sisi lain, UMKM menghadapi banyak permasalahan, yaitu terbatasnya modal kerja, SDM yang rendah, dan minimnya penguasaan ilmu pengetahuan dan teknologi [2]. Pemberdayaan UMKM di tengah arus globalisasi dan tingginya persaingan membuat UMKM harus menghadapi tantangan global, seperti meningkatkan inovasi, pengembangan SDM dan teknologi, serta perluasan area pemasaran. Hal ini perlu dilakukan untuk menambah nilai jual agar dapat bersaing dengan produk asing yang membanjiri industri dan manufaktur di Indonesia, mengingat UMKM adalah sektor ekonomi yang mampu menyerap tenaga kerja terbesar di Indonesia [3]. Salah satu upaya peningkatan daya saing UMKM di pasar global adalah dengan penguatan sisi manajemen, aliran informasi dan pemanfaatan teknologi informasi dan komunikasi.

Dalam beberapa dekade terakhir, penggunaan teknologi informasi (TI) dianggap strategi penting untuk diimplementasikan pada perusahaan. Meskipun penggunaan TI sudah umum dilakukan, proyek TI seringkali tidak sesuai dengan waktu ataupun anggaran yang telah ditetapkan.Terkait 
implementasi TI, UMKM memiliki kebutuhan yang berbeda dengan usaha skala besar, karena mayoritas UMKM memiliki sumber daya finansial yang lebih sedikit, ahli TI yang lebih sedikit/tidak ada, pimpinan organisasi yang terlibat pengambilan keputusan operasional, dan karyawan dengan kemampuan bervariasi karena memegang banyak peranan [4].

Salah satu aspek penting BPM adalah mengetahui seberapa jauh sebuah organisasi telah menerapkan aspek BPM yang dikenal dengan Business Process Maturity Model. Beberapa penelitian antara lain McCormack dkk, Skrinjar dan Trkman telah mengembangkan BPMM untuk menilai kematangan manajemen proses bisnis di perusahaan besar [5]. Er dan Chotijah (2016) menerapkan model untuk mengukur tingkat kematangan proses bisnis bagi usaha mikro, namun terdapat banyak hal yang sangat berbeda antara lain struktur organisasi yang sangat sederhana dan pemahaman tentang proses yang masih sangat rendah. Menurut Brocke (2014), praktik BPM yang baik seharusnya mempetimbangkan konteks perusahaan, dalam hal ini karakteristik perusahaan yang berbeda [6]. Hal ini dibuktikan oleh Andelkovic (2012) dengan hasil penelitiannya yang menyatakan bahwa dari setiap area pada BPM yang diterapkan pada perusahaan, area dukungan sistem informasi berada pada level rendah [7]. Hasil tersebut didapatkan berdasarkan kondisi perusahaan yang belum mengimplementasikan SI untuk tujuan spesifik, seperti CRM, SCM, dan lain-lain. Oleh karena itu, aspek dukungan sistem informasi tidak bisa diterapkan pada UMKM karena perbedaan kemampuan dalam sisi manajemen dan teknologinya [7].

Untuk itu maka pengukuran aspek TI diarahkan kepada pengukuran tingkat kesiapan TI. Terdapat beberapa penelitian tentang IT readiness, yaitu Premkumar (2003) yang menyatakan bahwa pemilik usaha memiliki peran penting dalam penentu keputusan terkait TI [8]. Selaras dengan visi strategis TI, kemampuan untuk melaksanakan visi tersebut juga penting untuk memperoleh manfaat dari investasi TI [6]. Menurut Caldeira dan Ward (2003), walaupun perusahaan kecil cenderung memiliki proses informal, perusahaan kecil dengan kemampuan manajemen cenderung lebih baik memanfaatkan TI daripada perusahaan yang tidak memilik kemampuan tersebut [7].

Studi ini berfokus pada pengukuran tingkat kematangan proses bisnis pada satu jenis UMKM yang diharapkan dapat memetakan kematangan proses bisnis dengan tingkat kesiapan teknologi informasinya. Dari penelitian ini diharapkan diperoleh profil UMKM garmen dari aspek kematangan proses bisnis dan kesiapan TI sehingga dapat dikembangkan strategi yang tepat dan terarah untuk tiap profil.

\section{LANDASAN TEORI}

\section{A. Proses Bisnis}

Proses bisnis merupakan sekumpulan aktivitas yang memerlukan satu atau lebih masukan dan membentuk suatu keluaran yang memiliki nilai yang diinginkan pelanggan [9]. Sebuah proses bisnis harus mempunyai: (1) tujuan yang jelas, (2) adanya masukan, (3) adanya keluaran, (4) menggunakan sumber daya, (5) mempunyai sejumlah kegiatan yang dalam beberapa tahapan, (6) dapat mempengaruhi lebih dari satu unit dalam organisasi, dan (7) dapat menciptakan nilai bagi konsumen [10].

\section{B. $U M K M$}

UMKM adalah singkatan dari Usaha Mikro Kecil dan Menengah. UMKM diatur berdasarkan Undang-undang Nomor 20 tahun 2008 tentang Usaha Mikro Kecil dan Menengah. Usaha Mikro adalah usaha produktif milik orang perorangan dan/atau badan usaha perorangan yang memenuhi kriteria aset tidak lebih dari Rp50 juta (tidak termasuk tanah dan bangunan tempat usaha) dan omzet per tahun tidak lebih dari Rp300 juta.

Usaha Kecil adalah usaha ekonomi produktif yang berdiri sendiri, yang memenuhi kriteria berikut, yaitu aset berjumlah lebih dari Rp50 juta tetapi kurang dari Rp500 juta dengan omzet per tahun lebih dari Rp300 juta tetapi kurang dari Rp2,5 M.

Usaha Menengah adalah usaha ekonomi produktif yang berdiri sendiri, yang dilakukan oleh orang perseorangan atau badan usaha yang memenuhi kriteria aset lebih dari Rp500 juta tetapi kurang dari Rp10 M, dan omzet per tahun berjumlah lebih dari Rp2,5 M tetapi kurang dari Rp50 M.

\section{Business Process Orientation Maturity Model (BPOMM)}

BPOMM merupakan suatu konsep yang membandingkan tingkat kematangan proses organisasi perusahaan terkait dengan standar industri. BPOMM dapat membantu perusahaan untuk dapat menentukan prioritas dalam meningkatkan luaran operasi perusahaan dan mengembangkan kapasitas kebutuhan strategi bisnis.

BPMM dilihat dari 9 aspek, antara lain pandangan strategis, definisi dan dokumentasi proses, proses pengukuran dan pengelolaan, struktur proses organisasi, manajemen manusia, proses budaya organisasi, orientasi pasar, pandangan pemasok, dan dukungan sistem informasi [8].

\section{IT Readiness}

IT readiness adalah sebuah terminologi yang diterapkan untuk menilai pengembangan infrastruktur tenologi informasi yang berfokus pada adanya fitur strategis, organisasional, dan fungsional yang merupakan kondisi awal yang harus dipenuhi oleh UMKM agar mampu memanfaatkan potensi IT.

Terdapat 3 elemen IT readiness menurut Dyerson, yaitu visi strategis, kemampuan manajemen proses, dan penerapan infrastruktur TI. Pada penelitian ini, konsep IT readiness digunakan untuk mengukur kematangan proses bisnis usaha kecil sektor garmen.

\section{METODOLOGI}

Pengerjaan studi ini tersusun atas beberapa langkah yang sistematis. Langkah-langkah pengerjaan studidari awal hingga akhir adalah sebagai berikut. 


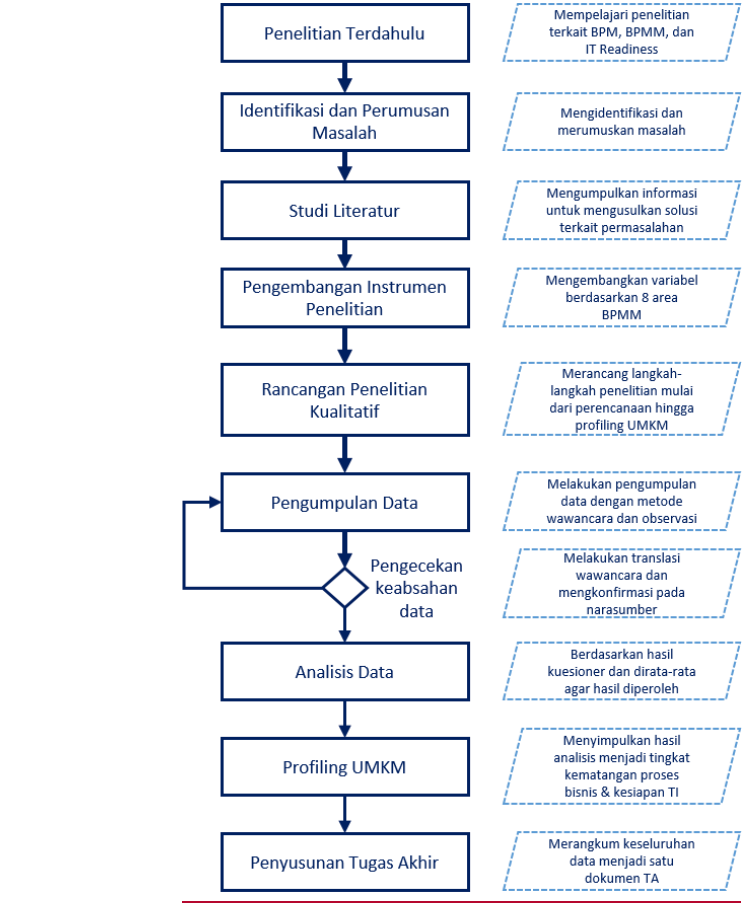

Gambar 1. Metodologi Penelitian

\section{HASIL DAN PEMBAHASAN}

Bab ini menjelaskan mengenai hasil dan pembahasan dari keseluruhan penelitian yang telah dilakukan.

\section{A. Analisis Tingkat Kematangan Proses Bisnis}

Pada subbab ini dilakukan pembahasan terkait analisis tingkat kematangan proses bisnis pada UD. JB. UD. JB adalah sebuah UMKM yang bergerak di bidang garmen. Karyawan UD. JB dibagi menjadi 2, yaitu delapan karyawan tetap dan 25 penjahit borongan, sehingga total karyawan yang dimiliki sejumlah 33 orang. Jumlah kekayaan bersih UD. JB berjumlah sebesar Rp300 juta dengan omzet per tahunnya sebesar Rp1,08 milyar.

UD. JB mendapat nilai 4.65 seperti yang tercantum pada Tabel yang dilatarbelakangi pemilik yang terlibat aktif dalam peningkatan proses bisnis, seperti mengagendakannya secara rutin dalam pertemuan. Proses bisnis yang ada didefinisikan dan didokumentasikan dengan baik dengan SPK, sehingga hasil kerja karyawan dapat dipertanggungjawabkan.

Tabel 1.

Kematangan Proses Bisnis

\begin{tabular}{|c|c|c|c|c|c|c|c|c|}
\hline Area & SV & DDP & MMP & POS & UK & POK & $\mathrm{TU}$ & VD \\
\hline Total & 28 & 29 & 37 & 31 & 20 & 29 & 21 & 16 \\
\hline Rata-rata & 5.6 & 4.83 & 5.28 & 4.42 & 4 & 4.83 & 3 & 5.3 \\
\hline \multicolumn{8}{|c|}{ Rata-rata keseluruhan } & 4.59 \\
\hline
\end{tabular}

Jika dilihat pada nilai masing-masing area yang diperoleh UD. JB, terdapat hasil yang bervariasi pada tiap area. Untuk area dengan rata-rata tertinggi adalah area Pandangan Strategis, sedangkan area dengan rata-rata terendah adalah Orientasi Pasar. Nilai tersebut dilatarbelakangi berbagai macam faktor, baik faktor internal maupun eksternal. Faktor internal yang paling berpengaruh adalah pemilik usaha yang terlibat secara aktif dalam peningkatan proses bisnis UMKM dengan berbagai cara, seperti mengagendakannya secara rutin dalam pertemuan dengan manajemen puncak maupun karyawan. Selain itu, proses bisnis yang ada pun didefinisikan dan didokumentasikan dengan baik dengan adanya SPK (Surat Perintah Kerja), sehingga hasil kerja karyawan selalu bisa dipertanggungjawabkan.

Akan tetapi, pada sisi orientasi pasar UD. JB memperoleh nilai yang rendah karena tidak melakukan studi pasar. Hal ini dipengaruhi oleh faktor eksternal, yaitu UD. JB hanya menyuplai produknya untuk satu pelanggan, yaitu PT. Co, sehingga UD. JB tidak memiliki kebutuhan untuk melakukan studi pasar maupun memantau aktivitas kompetitor. Selain itu, tingkat kepuasan PT. Co pun tidak diukur secara sistematis.

Area lain yang memperoleh nilai rendah pada UD. JB adalah area Manajemen Manusia. Hal ini dipengaruhi kondisi organisasi yang hanya memiliki satu pelanggan tunggal, sehingga walaupun karyawan memiliki bakat kreatif yang mungkin dijadikan terobosan peningkatan, hal tersebut sulit untuk diterapkan karena seluruh proses bergantung pada permintaan PT. Co. Karyawan juga tidak selalu mempelajari hal-hal baru, sehingga yang lebih difokuskan oleh UD. JB adalah menyamakan kecepatan pengerjaan.

\section{B. Analisis Kematangan Proses Bisnis Tiap Area}

Pada subbab ini akan dibahas hasil penilaian tingkat kematangan proses bisnis pada setiap area penilaian BPMM yang dilihat dari rata-rata akhir yang didapatkan pada tiap area.

1. Kategori Pandangan Strategis mendapat rata-rata 5.6 yang dilihat dari keterlibatan manajemen puncak terhadap usaha peningkatan proses yang tinggi. UMKM sangat bergantung pada pelanggan untuk roda bisnisnya, maka rencana peningkatan UMKM diarahkan oleh pelanggan. Keterlibatan pemilik UMKM juga dipengaruhi SDM yang ada.

Tabel 1.

Nilai Area Pandangan Strategis

\begin{tabular}{|c|c|c|}
\hline KODE & PRAKTEK & N Nilai \\
\hline sv1 & $\begin{array}{l}\text { Manajemen puncak secara aktif terlibat dalam } \\
\text { usaha peningkatan proses }\end{array}$ & 5 \\
\hline sv2 & $\begin{array}{l}\text { Tujuan-tujuan sub-proses diturunkan dari dan } \\
\text { terkait dengan strategi organisasi }\end{array}$ & 5 \\
\hline sv3 & $\begin{array}{l}\text { Peningkatan dan perancangan ulang proses bisnis } \\
\text { sering menjadi agenda dalam pertemuan } \\
\text { manajemen puncak }\end{array}$ & 6 \\
\hline sv4 & $\begin{array}{l}\text { Kebijakan dan strategi dikomunikasikan dan } \\
\text { disebarkan ke seluruh organisasi }\end{array}$ & 6 \\
\hline sv5 & $\begin{array}{l}\text { Rencana-rencana peningkatan untuk proses- } \\
\text { proses di tingkat tinggi dan diarahkan oleh } \\
\text { pelanggan dan strategi operasi }\end{array}$ & 6 \\
\hline & RATA-RATA & 5.6 \\
\hline
\end{tabular}

2. Kategori Definisi dan Dokumentasi Proses mendapat rata-rata 4.83 yang disebabkan kurangnya definisi dan dokumentasi proses, serta struktur yang sederhana memungkinkan UMKM untuk tetap menjalankan bisnis. Pendefinisian dan pendokumentasian tidak 
dilakukan secara formal karena keterbatasan SDM dan pengetahuan.

Tabel 2.

Nilai Area Proses Definisi \& Dokumentasi

\begin{tabular}{|c|c|c|}
\hline KODE & PRAKTEK & Nilai \\
\hline ddp1 & $\begin{array}{l}\text { Proses bisnis utama dan pendukung didefinisikan } \\
\text { dengan baik di dalam organisasi kami }\end{array}$ & 6 \\
\hline ddp2 & $\begin{array}{l}\text { Proses-proses dalam organisasi kami } \\
\text { terdokumentasikan dengan input dan output yang } \\
\text { jelas }\end{array}$ & 5 \\
\hline ddp3 & $\begin{array}{l}\text { Peran dan tanggung jawab untuk proses terdefinisi } \\
\text { dan terdokumentasikan dengan baik }\end{array}$ & 5 \\
\hline ddp4 & $\begin{array}{l}\text { Proses-proses dalam organisasi kami terdefinisikan } \\
\text { sehingga semua orang dalam organisasi tahu } \\
\text { bagaiman cara mereka bekerja }\end{array}$ & 6 \\
\hline ddp5 & $\begin{array}{l}\text { Deskripsi proses bisnis (model) tersedia untuk } \\
\text { setiap karyawan dalam perusahaan }\end{array}$ & 5 \\
\hline ddp6 & $\begin{array}{l}\text { Organisasi kami menggunakan metodologi standar } \\
\text { untuk menggambarkan proses bisnis }\end{array}$ & 2 \\
\hline & RATA-RATA & 4.83 \\
\hline
\end{tabular}

3. Kategori Proses Pengukuran dan Pengelolaan memiliki rata-rata 5.28 yang didapatkan dari beberapa faktor, antara lain UMKM menganggap adanya pengukuran maupun indikator kinerja tidak didefinisikan secara formal. Keseluruhan proses produksi berjalan sesuai dengan pengalaman. Proses bisnis UMKM jarang mengalami perubahan.

Tabel 3.

Nilai Area Proses Pengukuran \& Pengelolaan

\begin{tabular}{|c|c|c|}
\hline KODE & PRAKTEK & Nilai \\
\hline mmp1 & $\begin{array}{l}\text { Ukuran-ukuran proses terdefinisikan dan } \\
\text { terdokumentasikan untuk setiap proses }\end{array}$ & 4 \\
\hline mmp2 & Kinerja proses diukur dalam perusahaan & 5 \\
\hline mmp3 & $\begin{array}{l}\text { Target kinerja digunakan untuk setiap tujuan } \\
\text { proses }\end{array}$ & 5 \\
\hline mmp4 & $\begin{array}{l}\text { Indikator kinerja dikomunikasikan dalam } \\
\text { organisasi secara rutin }\end{array}$ & 6 \\
\hline mmp5 & $\begin{array}{l}\text { Hasil kinerja digunakan dalam menentukan target } \\
\text { peningkatan }\end{array}$ & 6 \\
\hline mmp6 & $\begin{array}{l}\text { Perubahan-perubahan untuk proses harus melewati } \\
\text { proses perubahan formal }\end{array}$ & 5 \\
\hline \multirow[t]{2}{*}{ mmp7 } & $\begin{array}{l}\text { Perubahan proses dikomunikasikan kepada semua } \\
\text { pihak terkait }\end{array}$ & 6 \\
\hline & RATA-RATA & 5.28 \\
\hline
\end{tabular}

4. Kategori Struktur Proses Organisasi mendapat nilai rata-rata 4.42 yang didasari dari struktur organisasi yang sederhana dan telah terpetakan dengan jelas, sehingga mendukung kelancaran pelaksanaan proses antar unit. Selain itu, mayoritas UMKM tidak memiliki manajer fungsional, sehingga penanggungjawab proses langsung dipegang oleh pemilik.

Tabel 4.

Nilai Area Struktur Proses Organisasi

\begin{tabular}{|c|c|c|}
\hline KODE & PRAKTEK & Nilai \\
\hline pos1 & $\begin{array}{l}\text { Pekerjaan-pekerjaan biasanya memiliki banyak } \\
\text { dimensi dan tidak pekerjaan sederhana }\end{array}$ & 3 \\
\hline
\end{tabular}

\begin{tabular}{cll}
\hline pos2 & $\begin{array}{l}\text { Struktur organisasi mendukung pelaksanaan proses } \\
\text { yang mulus antar departemen/bagian }\end{array}$ & 6 \\
pos3 & $\begin{array}{l}\text { Karyawan sering bekerja dalam tim yang terdiri } \\
\text { dari karyawan dari berbagai bagian yang berbeda }\end{array}$ & 2 \\
pos4 & $\begin{array}{l}\text { Kepemilikan proses didefinisikan dan dibuat } \\
\text { pos5 }\end{array}$ & $\begin{array}{l}\text { Pemilik proses ada pada tingkatan yang sama } \\
\text { dengan manajer fungsional }\end{array}$ \\
pos6 & $\begin{array}{l}\text { Pada hirarki mana seseorang yang bertanggung } \\
\text { jawab terhadap proses bisnis? } \\
\text { Bagaimanakah manajemen proses diatur dalam } \\
\text { organisasi? }\end{array}$ & 5 \\
pos7 & 5 & 4 \\
\hline
\end{tabular}

5. Kategori Manajemen Manusia mendapat nilai rata-rata 4 yang dipengaruhi tingginya tanggungjawab karyawan yang dilatarbelakangi faktor kekeluargaan yang dan jenis pekerjaan, yaitu karyawan borongan. Poin yang bervariasi pada area ini adalah adanya pelatihan terkait metode dan teknik peningkatan proses bisnis.

Tabel 5.

Nilai Area Manajemen Manusia

\begin{tabular}{clc}
\hline \hline KODE & \multicolumn{1}{c}{ PRAKTEK } & Nilai \\
\hline uk1 & $\begin{array}{l}\text { Karyawan terus menerus mempelajari hal } \\
\text { baru dalam pekerjaannya }\end{array}$ & 3 \\
uk2 & $\begin{array}{l}\text { Karyawan dilatih dalam metode dan teknik } \\
\text { peningkatan proses bisnis }\end{array}$ & 4 \\
uk3 & $\begin{array}{l}\text { Karyawan dilatih untuk mengoperasikan } \\
\text { proses yang baru atau diubah sebelum } \\
\text { diimplementasikan }\end{array}$ & 5 \\
Kary & $\begin{array}{l}\text { Kencawan bertanggung jawab untuk } \\
\text { Bakat kreatif karyawan digairahkan dengan } \\
\text { perbaikan-perbaikan berjenjang dan } \\
\text { terobosan }\end{array}$ & 2 \\
RATA-RATA
\end{tabular}

6. Kategori Proses Budaya Organisasi mendapat nilai 4.83 yang dilihat dari pemahaman karyawan akan keselarasan proses dan rasa kekeluargaan yang membuat karyawan tidak segan berkonsultasi. Terdapat hasil yang bervariasi terhadap terjadinya ketegangan yang terjadi saat karyawan berkumpul. Selain itu frekuensi pertemuan antar karyawan untuk membahas proses bisnis juga bervariasi. Ada UMKM yang menganggap pertemuan membuang waktu karena penjahit tidak berpengetahuan cukup dan hanya berorientasi pekerjaan, tapi ada UMKM yang rutin mengadakan pertemuan untuk evaluasi.

Tabel 6.

Nilai Area Proses Budaya Organisasi

\begin{tabular}{clc}
\hline \hline KODE & \multicolumn{1}{c}{ PRAKTEK } & Nilai \\
\hline \multirow{2}{*}{ pok1 } & $\begin{array}{l}\text { Istilah-istilah proses seperti input, output, } \\
\text { proses dan pemilik proses digunakan } \\
\text { dalam percakapan sehari-hari dalam } \\
\text { perusahaan }\end{array}$ & 5 \\
Rata-rata karyawan memandang bisnis \\
pokagai sekumpulan proses yang saling \\
pok3 & $\begin{array}{l}\text { Serkait } \\
\text { Saat anggota berbagai departemen }\end{array}$ & 6 \\
\hline \hline
\end{tabular}




\begin{tabular}{|c|c|c|}
\hline pok4 & $\begin{array}{l}\text { Karyawan dari berbagai bagian merasa } \\
\text { bahwa tujuan bagian mereka selaras }\end{array}$ & 6 \\
\hline pok5 & $\begin{array}{l}\text { Manajer dari berbagai departemen } \\
\text { mengadakan pertemuan secara regular } \\
\text { untuk mendiskusikan masalah-masalah } \\
\text { proses bisnis }\end{array}$ & 6 \\
\hline pok6 & $\begin{array}{l}\text { Orang dari berbagai departemen merasa } \\
\text { nyaman berdiskusi satu sama lain saat } \\
\text { dibutuhkan }\end{array}$ & 4 \\
\hline & RATA-RATA & 4.83 \\
\hline
\end{tabular}

7. Kategori Orientasi Pasar mendapat nilai rata-rata 3 yang dilatarbelakangi rendahnya respon terhadap kompetitor, karena aktivitas kompetitor tidak dipertimbangkan dalam proses harian.

Tabel 7.

Nilai Area Orientasi Pasar

\begin{tabular}{clc}
\hline \hline KODE & \multicolumn{1}{c}{ PRAKTEK } & Nilai \\
\hline tu1 & $\begin{array}{l}\text { Organisasi kami melakukan studi pasar } \\
\text { untuk menentukan kebutuhan dan } \\
\text { keinginan pelanggan }\end{array}$ & 2 \\
tu2 & $\begin{array}{l}\text { Karyawan memahami karakteristik produk } \\
\text { yang paling dihargai oleh pelanggan }\end{array}$ & 4 \\
tu3 & $\begin{array}{l}\text { Umpan balik yang diterima dari pelanggan } \\
\text { digunakan secara sistematis untuk } \\
\text { peningkatan proses internal }\end{array}$ & 4 \\
tu4 & $\begin{array}{l}\text { Organisasi kami secara sistematis dan } \\
\text { sering mengukur kepuasan pelanggan }\end{array}$ & 3 \\
tu5 & $\begin{array}{l}\text { Produk dan layanan dirancang dan } \\
\text { dikembangkan berdasarkan kebutuhan dan } \\
\text { ekspektasi pelanggan }\end{array}$ & 6 \\
tu6 & $\begin{array}{l}\text { Kami memantau aktivitas competitor } \\
\text { Kami merespon tindakan competitor } \\
\text { tu7 }\end{array}$ & 2 \\
\hline \hline
\end{tabular}

8. Kategori Pandangan Pemasok mendapat nilai rata-rata 5.3 yang dilihat dari hubungan jangka panjang dengan pemasok. Poin yang bervariasi pada area ini adalah tingkat kerjasama dengan pemasok untuk peningkatan proses. Ada yang memang telah meneken kontrak sehingga mendapatkan kemudahan dibandingkan yang lain, namun ada yang hanya melakukan aktivitas jualbeli dengan pemasok.

Tabel 8.

Nilai Area Pandangan Pemasok

\begin{tabular}{clc}
\hline \hline KODE & \multicolumn{1}{c}{ PRAKTEK } & Nilai \\
\hline vd1 & $\begin{array}{l}\text { Organisasi kami bermitra (misal } \\
\text { membentuk hubungan jangka panjang) } \\
\text { dengan pemasok kunci }\end{array}$ & 6 \\
vd2 & $\begin{array}{l}\text { Organisasi kami bekerjasama dengan } \\
\text { pemasok untuk meningkatkan proses } \\
\text { vd3 }\end{array}$ & $\begin{array}{l}\text { Perubahan pada proses bisnis secara } \\
\text { formal disampaikan kepada supplier }\end{array}$ \\
RATA-RATA & 5 \\
\hline \hline
\end{tabular}

\section{Keterkaitan Kematangan Proses Bisnis dengan Kesiapan} $T I$

Pada subbab ini dibahas keterkaitan hasil penilaian kematangan proses bisnis dengan kesiapan teknologi informasi pada UD. JB.

Tabel 9.

Kesiapan Penerapan TI

\begin{tabular}{cccc}
\hline \hline Area & Infrastruktur & Aplikasi & SDM \\
\hline Rata-rata & 2.25 & 2.25 & 2.2 \\
& \multicolumn{2}{r}{ Rata-rata keseluruhan } & 2.23 \\
\hline \hline
\end{tabular}

Untuk kematangan proses bisnis, jika dibandingkan dengan studi kasus UMKM lain, hal ini juga didukung dengan pemilik usaha yang melek teknologi dan memang paham manfaat teknologi untuk meningkatkan bisnisnya. Hal ini didukung pula oleh suami yang memang memiliki latar belakang IT sehingga pemilik UD. JB telah mengimplementasikan sistem absensi untuk mempermudah penggajian karyawan. Perangkat lunak perkantoran seperti Microsoft Office pun digunakan sehari-hari untuk kebutuhan dokumentasi dan manajemen persediaan. Pemilik UD. JB juga mendorong karyawannya untuk melek teknologi, terutama untuk admin dan desainer karena memang berkaitan dengan ranah kerjanya serta kepala-kepala unit yang harus tergabung dalam grup WhatsApp untuk memudahkan koordinasi antar bagian.

Tabel 10. Perbandingan BPOMM dan Kesiapan TI

\begin{tabular}{lc}
\hline \multicolumn{1}{c}{ Aspek } & Rata-rata \\
\hline Kesiapan TI & 2.23 \\
BPOMM & 4.59 \\
\hline \hline
\end{tabular}

Jika nilai rata-rata kematangan proses bisnis dan kesiapan penerapan TI yang diperoleh UD. JB dibandingkan seperti pada Tabel 10, nilainya berbanding lurus, yaitu cenderung sama-sama tinggi jika dibandingkan dengan studi kasus lain. Hal ini dilatarbelakangi proses-proses yang mulai diotomasi dengan TI, sehingga nilai kematangan proses bisnis UD. JB lebih tinggi dibandingkan studi kasus lain.

\section{KESIMPULAN DAN SARAN}

\section{A. Kesimpulan}

Beberapa kesimpulan yang bisa didapatkan dari penelitian studiini adalah:

1. UD. JB berada pada tingkat kematangan nomor 2 pada BPOMM, yaitu Defined dengan nilai akhir 4.59. Hal tersebut dilatarbelakangi faktor pemilik UMKM yang memang memahami pentingnya proses dokumentasi dan pengukuran kinerja, sehingga secara keseluruhan bisa dikatakan sudah tertata.

2. Berdasarkan delapan area BPMM, rata-rata tertinggi adalah Pandangan Strategis dikarenakan ukuran usaha yang terhitung kecil dengan proses dan struktur organisasi yang sederhana, sehingga operasinya sangat bergantung pada pemilik. UMKM juga bergantung pada 
pelanggan untuk meningkatkan pendapatan sehingga peningkatan proses diarahkan oleh pelanggan.

3. Area rata-rata terendah adalah Orientasi Pasar yang disebabkan tidak adanya pengukuran kepuasan pelanggan secara sistematis karena keterbatasan sumber daya dan faktor eksternal, yaitu pelanggan tunggal.

4. Untuk penilaian kesiapan teknologi informasi dibagi menjadi 3 kategori, yaitu rendah, sedang, dan tinggi. UD. JB masuk dalam kategori UMKM dengan kesiapan TI yang tinggi dengan nilai 2.23.

5. Berdasarkan tiga aspek yang diteliti pada area kesiapan teknologi informasi, aspek dengan rata-rata tertinggi adalah Aplikasi TI. Hal ini dikarenakan mayoritas poin pada area tersebut tidak memerlukan budget khusus dan tersedia gratis, seperti e-mail, sosial media, penggunaan internet, ataupun aplikasi perangkat lunak yang digunakan.

6. Kemudian disusul dengan aspek Infrastruktur TI dan SDM TI. Aspek Infrastruktur TI dilatarbelakangi kondisi UMKM yang memiliki alokasi dana terbatas. Selain itu, mayoritas UMKM melakukan bisnisnya secara offline, sehingga tidak membutuhkan infrastruktur yang mutakhir. Aspek SDM TI menjadi aspek rata-rata terendah karena proses bisnis UMKM tidak membutuhkan infrastruktur TI yang mutakhir, oleh karena itu UMKM tidak mengalokasikan karyawan khusus menangani TI.

7. Hasil rata-rata nilai BPMM dan kesiapan TI pada penelitian ini dapat dikatakan terkait, dimana ketika nilai kematangan proses bisnisnya tinggi, posisi kesiapan TI cenderung tinggi. Semakin TI diterapkan, maka proses bisnisnya semakin tertata dan matang.

Saran yang dapat dipertimbangkan untuk perbaikan penelitian ke depannya terkait dengan topik serupa adalah:

1. Penyesuaian terhadap instrumen yang ada pada acuan penilaian tingkat kematangan proses bisnis dengan kondisi terkini dari UMKM, sehingga hasil yang didapatkan lebih merepresentasikan keadaan yang ada.

2. Penggunaan kuesioner tambahan untuk menilai kesiapan teknologi informasi secara menyeluruh agar didapatkan hasil yang lebih maksimal

3. Menggunakan studi kasus yang memiliki karakteristik yang sama, sehingga dapat dibandingkan dengan lebih menyeluruh.

4. Menggunaan studi kasus UMKM dengan sektor yang berbeda, seperti industri pangan dan furnitur, agar dapat diketahui perbedaan tingkat kematangan organisasi ditinjau dari perbedaan jenis industri yang diterapkan.

\section{DAFTAR PUSTAKA}

[1] Sudaryanto, Strategi Pemberdayaan UMKM Menghadapi Pasar Bebas ASEAN. Kementerian Keuangan Republik Indonesia, 2014.

[2] Sudaryanto, "Evaluasi kesiapan UKM Menyongsong Pasar Bebas ASEAN (AFTA) : Analisis Perspektif dan Tinjauan Teoritis," $J$. Ekon. Akunt. dan Manaj., vol. 1, 2002.

[3] Sudaryanto, "The Need for ICT-Education for Manager or Agribusinessman to Increasing Farm Income: Study of Factor Influences on Computer Adoption in East Java Farm Agribusiness," Int. J. Educ. Dev., vol. 7, no. 1, pp. 56-67, 2011.

[4] D. Fink, "Guidelines for the successful adoption of information technology in small and medium enterprises," Int. J. Inf. Manage., vol. 18, 1998.

[5] McCormack, Business process orientation - Gaining the e-business competitive. Florida: St. Lucie Press, 2011.

[6] A. Haug, "IT readiness in small and medium-sized enterprises," Ind. Manag. Data Syst., vol. 11, no. 4, 2011.

[7] M. Caldeira, "Using resource based theory to interpret the successful adoption and use of information systems and technology in manufacturing small and medium-sized enterprises," Eur. J. Inf. Syst., vol. 12, no. 2, 2003.

[8] G. Premkumar, "A meta analysis of research on information technology implementation in small business," J. Organ. Comput. Electron. Commer., vol. 13, no. 2, 2003.

[9] J. A. Champy, Reengineering the Corporation: A Manifesto for Business Revolution. New York: Harper Business Essentials, 1993.

[10] S. Systems, "The Business Process Model," 2004. [Online]. Available:

http://www.sparxsystems.com/downloads/whitepapers/The_Busines s_Process_Model.pdf. 